India, Agricultural Research Institute, New Delhi, India. It is intended to publish papers on both pure and applied entomology, besides short notices about now books and reviews of recent research, etc. The chief editor is Dr. Hem Singh Pruthi who, with five other Indian entomologists, forms the editorial board. The present number is rell produced; it contains eight scientific articles and runs to $137 \mathrm{pp}$. together with illustrations. We wish this new journal every success, and if it results in the 'localization' of much future Indian entomological work within its pages, instead of the present diversity of sources for its publication, it will prove a definite boon to workers all over the world.

\section{Bibliography of Drosophila}

STODENTs of genetics have for a long timo past needed a guide to the immense amount of genetical work done on Drosophila. This noed has been supplied by the publication of $\&$ "Bibliography on the Genetics of Drosophila" by the Imperial Bureau of Animal Breeding and Genetics. Dr. H. J. Muller has compiled not only papers of special interest to workers on Drosophila, but also those more general papers which shed light on problems which affect both Drosophila and gonetical thought. The bibliography is particularly valuable in that it provides cross references whero several authors are involved in ono paper, and in the adequato roference to Russian literature.

\section{Chemical Club}

THe Chemical Club is continuing to function at its house at 2 Whitehall Court, London, thero being good air raid shelters in the premises. There is a feeling that tho Club will bo used moro and moro during time of war, since enlarged acquaintanceship and cheerful association are definite factors in the present national effort. The annual general meoting will be hold at the Club on Tuesday, November 14, at 2 o'clock. Tho popularity of lunchtimo meetings since the war started is expected to result in a good attendance. The report of the executivo committee for the year 1938-39 speaks of a year of successful social and other activities. The Committee has nominated for the ensuing year Mr. F. Arnold Green as president, Dr. H. E. Cox as chairman of the executive committee, and the continuation in office of the honorary treasurer and honorary secretary, Dr. S. I. Levy and Mr. F. J. Bullen respectively. The Committeo will recommend to the annual general meeting that in view of the number of clubs which are offering temporary membership to uniformed n.embers of H.M. Forces, the Chemical Club should provide parallel concessions by offering facilities, at a nominal subscription, to those who, although not in uniform, are engaged in London on Government work. This temporary measure is one likely to be highly prized by chemists and others so situated.

\section{World Power Conference}

IR. G. J. T. BAKken, chairman of the Netherlands National Committee of the World Power Conference, has agreed to become acting chairman of the Inter- national Executive Council of the Conference during tho War. Correspondence intended for the International Executive Council should be addressed to the Secretariat, International Executive Council, World Power Conference, Vereeniging voor Congressen op Electrotechnisch en Aanverwant Gebied, Utrechtschereg 210, Amhem, Holland. Corre. spondence for the British National Committeo should, as at present, be addressed to 36 Kingsway, I/ondon, W.C.2. Orders for any World Power Conference Transactions should bo sent to Messrs. Percy Lund, Humphries and Co., Ltd., Country Press, Bradford. Orders for the publications of the Central Office of the World Power Conference, including the Statistical Year-book of the World Power Conference, should be directed to the British National Committeo. Special arrangements have, however, been made with respect to "Technical Data on Fuel", orders for which will bo dealt with by the Secretary, Society of British Gas Industries, Uplands, Epsom Road, Guildford, Surrey.

\section{Announcements}

Prof. E. Scurōdinger is now in Dublin, and is dolivoring is course of lectures which began on November 3 at University College, Dublin, under the title "An Elementary Introduction to Wave Mechanics".

Dr. ICIE MIACY-HooBLER, director of the research laboratory of the Children's Fund of Michigan, Detroit, has been awarded the 1939 gold medal and the thousand dollars prize of the Borden Company for outstanding research achievement in npplied nutrition.

IN view of the importance of chemical engineering at the present juncture, the Ramsay Laboratory of Chemical Enginecring at University College, London, has reopened, and students will bo accopted for training in chemical engineering and research forthwith.

Nentings of the Quokett Microscopical Club are taking place on the third Saturday aftermoon of each month at 2.30 p.m. in the Club's rooms at 11 Chandos Street, Cavendish Square, Iondon, W.1.

The general discussion on "The Properties and 'Iesting of Heat Insulating Materials" organized by the Joint Committee on Materials and their Testing in conjunction with the Institution of Gas Engineors arranged for November 23, has been postponed.

Of the two million babies born annually in the United States seventy-five thousand aro stillborn, and thirty-nine thousand die during the first month of life. Approximately twelve thousand mothers dio from causes directly related to child-bearing, many of which are preventable through combined individual and community action. 